\title{
Geodiversity: An integrative review as a contribution to the sustainable management of the whole of nature
}

\author{
J. Brilha ${ }^{\mathrm{a}, *}$, M. Gray ${ }^{\mathrm{b}}$, D.I. Pereira ${ }^{\mathrm{a}}$, P. Pereira ${ }^{\mathrm{a}}$

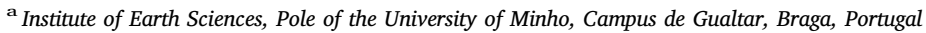 \\ ${ }^{\mathrm{b}}$ School of Geography, Queen Mary, University of London, Mile End Road, London, E1 4NS, UK
}

\section{A R T I C L E I N F O}

\section{Keywords:}

Geodiversity

Abiotic nature

Sustainability

Natural capital

Ecosystem services

Agenda 2030

\begin{abstract}
A B S T R A C T
In 2015, the United Nations adopted the 2030 Agenda for Sustainable Development and its 17 Sustainable Development Goals (SDG) aiming to achieve a better world for the entire human population. In spite of the fact that human development is dependent on nature and its resources, the non-living (abiotic) natural resources and processes are persistently neglected in international and national policies that foster sustainable development. This paper reviews the geodiversity concept and makes the links with well-established concepts and strategies, namely the ones related with natural capital and ecosystem services, to demonstrate that the UN SDG can only be achieved if the elements and processes of geodiversity are definitely considered in the global agenda.
\end{abstract}

\section{Introduction}

Planet Earth, third rock from the Sun, a fundamentally physical body with an outer living layer unique among the planets of our solar system. And it is this living outer skin that dominates the fields of nature conservation and sustainability. Most people now understand the word "biodiversity" and the need to save the world's many endangered species. They may even understand how society benefits from the world's biodiversity in terms of the "ecosystem services" that it provides from medicines and pharmaceuticals, to forest and fibre products, from genetic manipulation to crop pollination by insects. Milton (2002, p 115) emphasized the dominance of biodiversity in saying that "Diversity in nature is usually taken to mean diversity of living nature...". But fewer people understand that our planet is also physically diverse and that this non-living, abiotic nature or "geodiversity" is rarely appreciated by the public yet without which our modern society could not exist. And if society is to continue to live sustainably on the planet, it is important that we understand the values that geodiversity brings and act to conserve, manage and plan these georesources. With reference to a key diagram with geodiversity at its heart (Fig. 1), this paper aims to explain the principles of geodiversity, the benefits it brings to society, how it is assessed and the measures being taken to conserve and manage it.

\section{The concept of geodiversity}

Geodiversity can be defined as "the natural range (diversity) of geological (rocks, minerals, fossils), geomorphological (landforms, topography, physical processes), soil and hydrological features. It includes their assemblages, structures, systems and contributions to landscapes" (Gray 2013, p. 12) (Fig. 1). This author also provides an outline of the geodiversity of the Earth (Gray, 2013, Chapter 3) but the content of any geology textbook (e.g. Marshak, 2012) demonstrates that our planet has an extraordinary diversity of minerals, rocks, fossil species, soils, landforms, landscapes, physical processes, etc.

The word and concept of "geodiversity" were first introduced in 1993 shortly after the Convention on Biological Diversity was agreed at the Rio Earth Summit in 1992. In other words, once the word "biodiversity" came into general use, it was almost unavoidable that the term "geodiversity" would also be introduced since geoscientists recognized that they also study very diverse phenomena on our planet. And so, in 1993 a number of geoscientists independently started using the term "geodiversity" (e.g. Wiedenbein, 1993; Sharples, 1993). Subsequently the term has been used around the world and is now internationally accepted. For example, in Australia, Kiernan, $(1996,1997)$ used the term in classifying glacial and coastal landforms, and the Australian Natural Heritage Charter (Australian Heritage Commission, 1996, 2002) incorporates "geodiversity" throughout its several Articles. Article 5, for example, states that "Conservation is based on respect for biodiversity and geodiversity. It should involve the lease possible intervention to ecological processes, evolutionary processes and earth processes". In Scandinavia, the Nordic Council of Ministers published an excellent book on geodiversity in Sweden, Norway, Finland, Denmark and Iceland (Johansson, 2000) with an English Summary (Nordic

\footnotetext{
* Corresponding author.

E-mail address: jbrilha@dct.uminho.pt (J. Brilha).
} 


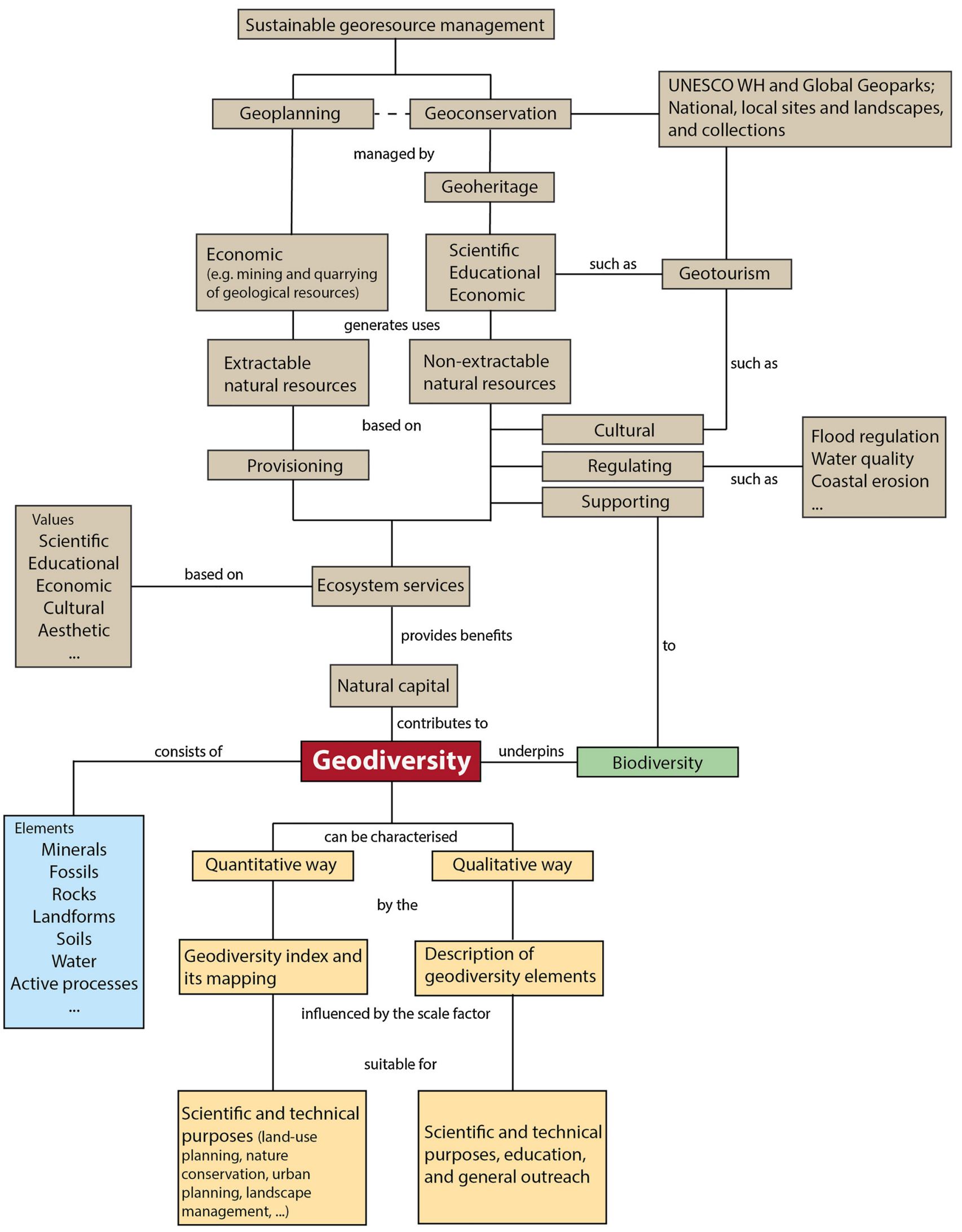

Fig. 1. Network of definitions and relationships starting from the concept of Geodiversity. See text for a detailed explanation. 
Council of Ministers, 2003). The term "geodiversity" is now widely used across Europe and the International Union for the Conservation of Nature (IUCN), which is strongly focused on bioconservation, created a Geoheritage Specialist Group in 2013 that "provides specialist advice on all aspects of geodiversity in relation to protected areas and their management".

The early history of the use of the word "geodiversity" was reviewed in Gray (2008) who referred to the geodiversity concept as a "geological paradigm". The theory of geodiversity, its values and its application to geoconservation are more fully explored in Gray (2013).

\section{How to characterise geodiversity}

Geodiversity can be characterised in two different ways (Fig. 1), generally supported in 3 main questions: "What?" is related with the type of geodiversity elements present in a certain area and its spatial distribution, which determines the scale of the analysis; "Why?" means the goals for its characterisation and cartographic representation, as education, outreach, land-use planning, etc; "How?" deals with the selection of the methodology(ies) and criteria for the geodiversity characterisation and assessment. The answer to this last question is strongly connected with the first two, depending on the geodiversity elements and on the reasons to characterise them. Therefore, there are different examples to describe the geodiversity of a certain area that reflect qualitative and quantitative approaches.

\subsection{Qualitative approach}

A qualitative characterisation of geodiversity consists of a description of the geodiversity elements in a given area and eventually an explanation on their values. This qualitative approach includes proposals that are based on expert views and where the geodiversity values are labelled or rated but always in a non-numerical form. Varying from very simple to very complex, a qualitative characterisation of geodiversity provides the identification of specificities in the study area. Sometimes, these descriptions are used to establish a link between geodiversity and geoheritage values (Kozłowski, 2004; Panizza, 2009; Ferrero et al., 2012; Bradbury, 2014). In the UK, Local Geodiversity Action Plans are being used as management tools applied to different type areas such as cities, counties, or protected areas (Dunlop et al., 2018). Recent proposals (that will be discussed below regarding the geodiversity ecosystem services theme (Gordon, 2012, Gordon and Barron, 2013; Gray, 2011, 2012, 2013; Gray et al., 2013; Hjort et al., 2015) can be related with this qualitative approach. Despite the absence of cartographical outputs in the majority of the qualitative characterisations of geodiversity, the maps that can be produced are quite similar to the traditional geological maps representing spatial units with well-defined boundaries comparable to the geological units (Silva, 2008). Therefore, the qualitative approach provides rather the spatial distribution of geodiversity elements instead of the spatial distribution of their diversity.

\subsection{Quantitative approach}

The quantitative approach intends to express in a more objective way the spatial variability of geodiversity elements. Hence, these analyses are mostly based on a set of numerical parameters and indicators to detect the diversity of geological features in a certain area. Although some parameters may derive from field measurements and remote sensing, the majority of the quantitative procedures rely on map analyses of the diversity, the frequency and the distribution of geodiversity elements in a given area (Carcavilla et al., 2007). This supports the quantification and comparison of these features divided by predefined natural regions or units (Serrano and Ruiz-Flaño, 2007; Benito-Calvo et al., 2009) or by artificial units as grid cells outlined in maps (Zwoliński, 2009; Hjort and Luoto, 2010; Pereira et al., 2013). The calculation of indices through the use of GIS procedures and map algebra is of particular relevance (e.g. Forte et al., 2018). Indices reflect the concentration of a given feature or of a set of characteristics of the natural environment, reducing the amount of data and increasing the comparability of results for similar typological research areas (Zwoliński et al., 2018). Map algebra is used to compile the results of partial assessments of geodiversity elements through algebraic and logic operations and functions using raster or vector spatial data. The cartographic output of these procedures can be a complete geodiversity map or partial - geomorphological, lithological, pedological, hydrological, or palaentological diversity - indices maps (Pereira et al., 2013). In opposition to the qualitative approach, studies relating quantitative analysis of geodiversity with geoheritage values are scarce (e.g. Ruban, 2010). A detailed review of quantitative methods used to assess geodiversity is presented by Zwoliński et al. (2018).

\subsection{Scale and potential use}

Scale is an important factor to consider in geodiversity characterisation procedures, independently of being qualitative or quantitative approaches. These procedures can vary from very general to very detailed depending on the availability of spatial data at an appropriate scale, including in its digital form. Smaller areas generally have more focused studies with high detail on geodiversity elements. For instance, at a country-level study, the lithological diversity is generally characterised by the variability of the major rock types, though at a county or municipal level the same analysis will consider all rock subtypes. Therefore, the accuracy and detail of data to support the geodiversity characterisation is crucial, mainly in more detailed quantitative studies based in map algebra procedures.

Despite being based on the knowledge of the expert and on detailed data, a qualitative description of geodiversity carries a degree of subjectivity that is not compatible with comparison or verification of results. Furthermore, the cartographic outputs related with this qualitative approach are more suitable for education or outreach purposes because they are more understandable by non-specialists.

A quantitative characterisation seems to be more useful to researchers. Several recent studies and methodologies present and discuss geodiversity indices using map algebra with GIS techniques (Hjort and Luoto, 2012; Pereira et al., 2013; Malinowska and Szumacher, 2013; Silva et al., 2013, 2015; Melelli, 2014; Pellitero et al., 2014; Kot, 2015; Martinez-Grana et al., 2015; Manosso and Nóbrega, 2016; Argyriou et al., 2016; Araujo and Pereira, 2017; Forte et al., 2018). The objectivity and simplicity of using GIS analysis of geographical data during the data collection allow cartographic representations of geodiversity or partial geodiversity indices and the overlay with other types of spatial data. The quantitative characterisation of geodiversity is thus more appropriate for land-use planning, nature conservation and landscape management. Besides, some of these works recognize new trends in applied studies of geodiversity such as the possibility of comparing the results of geodiversity assessments with other natural or cultural features like biodiversity (Jačková and Romportl, 2008; Hjort et al., 2012, 2015; Räsänen et al., 2016, Najwer et al., 2016; Tukiainen et al., 2016).

\section{Natural capital}

"Capital" is a term used in economics to denote a stock of assets used to provide a flow of funds to establish or run a business. The term "natural capital" has been the subject of somewhat differing interpretations but the consensus view is that it includes the stock of both biotic and abiotic assets in nature (Barbier \& Heal, 2006; Barbier, 2011; Helm, 2015; Costanza et al., 2017). Thus, the World Forum on Natural Capital defines "natural capital" as the "world's stocks of natural assets, which include geology, soil, air, water and all living things". These are sometimes also referred to as environmental assets. The UN System of 
Environmental-Economic Accounting - Central Framework (SEEA CF) defines environmental assets as "the naturally occurring living (biotic) and non-living (abiotic) components of the Earth, together constituting the biophysical environment, which may provide benefits to humanity". From this, it is clear that geodiversity contributes to the stock of natural capital and has been brilliantly exploited by society over many millennia from the Stone Age and Iron Age to the current Oil Age and Silicon Age. In spite of this, many studies involving natural capital have focused on biotic components of the environment.

An important distinction is made between renewable and non-renewable natural capital. In the case of renewable resources, the key management approach is that "what is damaged should be compensated for in gains elsewhere" (Helm, 2015) as in biodiversity off-setting. Some abiotic resources are renewable (e.g. freshwater) and some landscapes can be restored (e.g. by quarry or river restoration). However, many abiotic resources are non-renewable (e.g. minerals, oil, gas) and ought to be subject of minimised use, recycling, etc. in order to meet the requirements of sustainability and intergenerational equity.

\section{Ecosystem services and geodiversity}

As referred to above, natural capital can be exploited to provide benefits for society. These benefits were originally termed "nature's services" (Daily, 1993) but are now generally referred to as "ecosystem services" which are the goods and services that humans derive from nature. Building on Tansley's definition of an ecosystem as "the whole system,. . . including not only the organism-complex, but also the whole complex of physical factors forming what we call the environment" (Tansley, 1935), Article 2 of the Convention on Biological Diversity defines an ecosystem as "a dynamic complex of plant, animal and micro-organism communities and their non-living environment interacting as a functional unit". The implication of this definition is that ecosystems include abiotic elements but only where they are interacting with biotic elements (Gray, 2013). As a result, most assessments of ecosystem services do not include the full array of services associated with geodiversity. For example, Diaz et al. (2015) state that "non-living natural resources....are considered as part of nature, but their direct benefits are not the focus of the IPBES" (Intergovernmental Platform on Biodiversity and Ecosystem Services). Also, the UK National Ecosystem Assessment (UKNEA) (2011) 'focuses on 'ecosystem services' that are derived from ecosystem processes including biotic interactions; as such, it does not provide an assessment of 'environmental services' that may be purely abiotic in origin such as minerals extracted from the ecosystem" (Brown et al., 2011, para 1.3.1). Despite this statement, Gray et al., 2013, Table 1) found many examples of abiotic nature referred to in the UKNEA. There is also inconsistency in the treatment of water, which, despite being abiotic, is included in many classifications of ecosystem services (e.g. Brouwer et al., 2013). The Common International Classification of Ecosystem Services (CICES v4.3; Haines-Young and Potschin, 2013) had a separate "accompanying classification of abiotic outputs from natural systems" but in a survey of users, a majority felt that abiotic services should be integrated into CICES (HainesYoung, 2016). Furthermore, Van der Meulen et al. (2016) argue that abiotic flows should be an inherent part of ecosystem services. However, in the most recent version (CICES v5.1, Haines-Young and Potschin, 2018) the abiotic section has been expanded but kept apart from the biotic section of the table. In conclusion, the current status of abiotic services within the ecosystem services approach is unsatisfactory, inconsistent and confusing, but if abiotic services are excluded, there must be a danger of a radical undervaluing of the contribution of all nature to human well-being.

For this reason, some authors have carried out separate assessments of the services associated with geodiversity (Gray, 2011, 2012, 2013; Gordon and Barron, 2011, 2012; Gordon et al., 2012) and have referred to these as either "abiotic ecosystem services" (Gordon and Barron, 2012; Gray, 2013) or "geosystem services" (Gray, 2011; Van Ree and
Beukering, 2016). These benefits can be either tangible (e.g. coal, oil) or intangible (e.g. the mental health benefits from experiencing an unspoilt natural environment). Thus, the presence of natural capital leads to both "ecosystem services" (biotic nature) and "geosystem services" (abiotic nature) though there are several examples of where they overlap (see Table 1). For example, flood regulation by infiltration is partly achieved by plant interception and partly by free-draining subsoils. As a consequence, there is a strong case for adopting an integrated set of "environmental services" or "nature's services (Daily, 1993) (see Table 1). Geosystem services are related to their general value to society, whether scientific, educational, economic, cultural, aesthetic, functional, etc. (Fig. 1).

The ecosystem approach is now the key international policy driver whereby decision-makers make quantitative and qualitative judgements about the value of nature and its sustainable management. Three classification systems for ecosystem services have emerged in recent years:

1 The Millennium Ecosystem Assessment (2005);

2 The Economics of Ecosystems and Biodiversity (TEEB, 2010);

3 The Common International Classification of Ecosystem Services (CICES, v5.1) (Haines-Young \& Potschin, 2018).

The system used here is the Millennium Ecosystem Assessment (MA), which was also used by the UK National Ecosystem Assessment (2011). This classifies the services into 4 groups:

- regulating services - the ways in which natural processes regulate the environment;

- supporting services - those processes that support natural environments;

- provisioning services - the natural materials that are used by society;

- cultural services - the non-tangible elements of the natural environment that benefit society in a spiritual or cultural sense.

The contribution of geodiversity elements and processes to ecosystem services is founded on a set of values (Fig. 1 and Table 1). Gray (2013) presents with detail each one of these different types of values scientific, educational, economic, cultural, aesthetic, etc. - and establishes the link between type of value and type of use. For instance, the aesthetic value of a geological site leads to a touristic use of it, which has also a relation with the economic value of the site.

The concept of planetary boundaries was introduced by Rockström et al. (2009b) and is somehow related with natural capital and ecosystem services. Planetary boundaries set thresholds for human societies to use the limited capacity of nine Earth system processes, based on the understanding and resilience of this system. According to these authors and also Steffen et al. (2015) and Jaramillo ö Destouni (2015), among others, the assessment made of several systems reveal that these thresholds have already been exceeded. So, while natural capital and ecosystem services are concentrated in the resources of nature and in the direct and indirect benefits they provide to human societies, planetary boundaries try to allow for the fact that some of these benefits are already compromised due to the anthropic overuse of Earth systems. However, the nine planetary boundaries that were defined by the above mentioned authors maintain the systematic problem already mentioned and that this paper tries to draw attention to: the role of geodiversity is systematically underestimated when sustainability is being considered.

\subsection{Regulating services}

Earth elements and processes provide unique conditions for the presence of life. Global regulating services such as the magnetic field or the gradual release of the Earth's internal heat are usually taken for granted and unchanged. Until now, only science-fiction movies (e.g. 
Table 1

Examples of benefits provided by geodiversity (after Gray, 2013). These benefits are classified according to the ecosystem approach (Millennium Ecosystem Assessment, 2005; Haines-Young \& Potchin, 2013), and to the main divisions of each type of service. The column "Delivery" indicates if the benefits directly assure human well-being (Human) or support ecosystems (Eco). The column "Type" indicates if the genesis of the benefit is just geological (Geo) or the result of biological and geological processes (Bio/Geo).

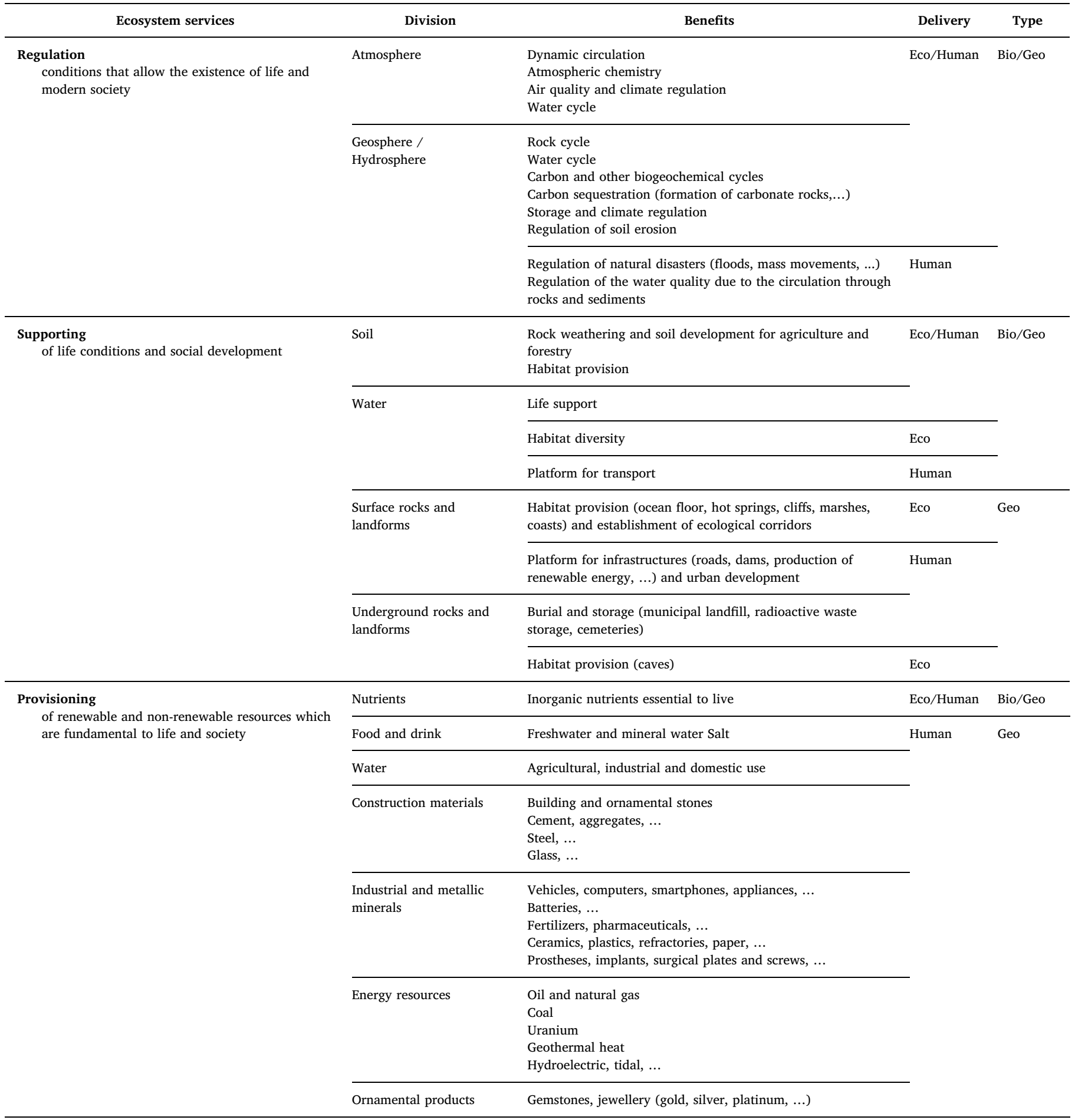


Table 1 (continued)

\begin{tabular}{|c|c|c|c|c|}
\hline Ecosystem services & Division & Benefits & Delivery & Type \\
\hline \multirow{5}{*}{$\begin{array}{l}\text { Cultural } \\
\text { Contribution of the physical environment to the } \\
\text { development of cultural activities }\end{array}$} & Wellness and health & Hydrotherapy (spas) & Human & Geo \\
\hline & & $\begin{array}{l}\text { Artistic inspiration } \\
\text { Natural landscapes for physical and mental health }\end{array}$ & & $\mathrm{Bio} / \mathrm{Geo}$ \\
\hline & Recreation & $\begin{array}{l}\text { Tourism activities (pedestrian trails, viewpoints, caves, ...) } \\
\text { Sport (rock climbing, ...) }\end{array}$ & & \\
\hline & Human history & $\begin{array}{l}\text { Sacred and historic sites } \\
\text { Use of stone in monuments and other buildings }\end{array}$ & & \\
\hline & Knowledge & $\begin{array}{l}\text { History and evolution of the Earth } \\
\text { Origin and evolution of life } \\
\text { Paleoclimates and paleoenvironments }\end{array}$ & & \\
\hline
\end{tabular}

"Meteor", 1979; "Armageddon", 1998; "Deep Impact", 1998; "The Core", 2003; "The Day After Tomorrow", 2004; "2102", 2009) and occasional news (e.g. about the eventual explosion of supervolcanoes such as Yellowstone, USA, Campi Flegrei, Italy, or Toba, Indonesia) suggest global catastrophic effects caused by changes in the current terrestrial natural conditions. However, great changes in the planet's geodynamics (e.g. eruption of supervolcanoes, meteor collisions, climate changes) have caused in the past great impacts on the established surface conditions and have played a decisive role in the way life evolved until today.

Other global services, like the hydrological cycle and the carbon cycle run in a perfect articulation between terrestrial, oceanic and atmospheric conditions. The retention of large amounts of carbon in sedimentary rocks and its release into the atmosphere are regulated by sedimentary and volcanic processes (Gray, 2013). Nevertheless, the crucial role of atmosphere and oceans as regulating services at various scales should be noted, but predominantly at the global scale (Gray, 2013). The atmosphere's role in the protection of the sun's radiation (specially the ozone layer), oxygen and carbon dioxide supply, and the vital role of water are well-known, either for ecosystems and for human well-being.

At a regional and local scale, rocks and geological processes also play fundamental regulating service roles. For example, river flows are regulated by the input of water provided by the circulation of underground water that, in many cases, feeds the superficial flow even during long periods of drought. Weathering, erosion, river transport of sediments and nutrients, depuration of water during its underground circulation and many other terrestrial services are vital for the equilibrium of life-support systems (Gray, 2013).

\subsection{Supporting services}

Geosystem supporting services provide human well-being indirectly through ecosystems and directly to allow the building of infrastructures and the development of vital activities.

Rock weathering is a crucial stage of the rock cycle that includes formation and renovation of soils. This geological process, that can include biological processes, results in the fragmentation of rocks, production of secondary minerals, release of nutrients, increase of porosity, allowing the incorporation of organic material. Porosity and the new minerals, especially clays, are fundamental in retaining water that dissolves free elements that are basic for the growth of plants. Being so slow and natural, this process is often ignored as a fundamental service in the ecosystem approach. Together with water, soils must be looked at as the most precious support for life, in the long-term that clearly exceeds the human time-scale.

Geodiversity elements and processes also provide different habitats in oceans and on continents, including deep and shallow waters, mountains, rivers, beaches, caves, soils, hydrothermal vents, and many others. In addition to these benefits for ecosystems, including agriculture and fishing, geodiversity provides diverse platforms to the development of human societies. Relief and rock resistance are essential factors in the planning of dams, bridges and skyscrapers. Airports, roads, railways and all superficial constructions are related to geomorphology (Gray, 2013). Landfills and cemeteries are the most wellknown burial services but others are being developed, for example for the storage of radioactive wastes and carbon sequestration (Gray, 2013).

\subsection{Provisioning services}

A close observation of the materials around us allows us to understand why extractable natural resources have been the basis of societies since the Stone Age. Some of these goods have organic origins, such as food for human consumption or wood used as a fuel or in timber construction (Haines-Young ö Potschin, 2013; Gray, 2013). However, once the basic human needs that include the renewable water resource are fulfilled, human social development is based on non-renewable extractable resources known as geological resources. Geological resources include a large set of potential raw materials - solid, gas or liquid elements - presenting optimum concentrations for its exploitation, in or on the Earth's crust (Mata-Perelló et al., 2011). They have been used since the initial stages of mankind and play an essential role in the economic and social development of humanity. Wisely used, mineral resources create wealth, employment, a vital social and natural environment and peace (Pohl, 2011).

Excepting water, traditionally geological resources are identified as non-renewable: industrial rocks and minerals, metallic minerals, energy materials, and gemstones, but a lot of classifications are acceptable based on the use, value, or composition. A more precise meaning and use of terms like mineral deposits, mineral reserves and geological resources are related to the economic viability of profitable mining (Wagner and Wellmer et al., 2011).

Occasionally, raw materials are consumed directly but most of these materials are processed by industry that generates the goods needed to sustain the well-being of today's society. Renewable resources like water and inorganic nutrients are also related to geological processes. The fact that they also support ecosystems justifies their inclusion either in the provisioning (Hjort et al., 2015) or in supporting services.

\subsubsection{Water}

Being an extractable resource, freshwater has the particularity of a renewable good. The inclusion of water in ecosystem services is due to the clear relationship between ecosystems and water (Karabulut et al., 2016; Vanham 2016) and to the importance of ecosystems for the regeneration of water quality. Nevertheless, water is also an integral part of geodiversity and a physical or abiotic component of ecosystems. Usually two important reservoirs of water are considered: the blue 
water - liquid water in rivers, lakes, wetlands and aquifers, and green water - the soil water held in the unsaturated zone, formed by precipitation and available to plants (Rockström et al., 2009a; Vanham, 2016). Together, blue and green water, are a vast resource that precedes the origin of life and that should be also understood as a fundamental component of geosystems. During the terrestrial sub-cycle, most of the fresh water fills the aquifers, circulates in the rocks, dissolves minerals and regenerates its quality, making it suitable for various uses. On the surface, distribution of drainages, watersheds, springs, lakes and the location of dams are linked to lithology, tectonics, stratigraphic contacts, and geomorphic features (Santucci, 2005).

Under a provisioning point of view, water has also domestic (municipal water use), agricultural (food production including livestock), industrial and energy uses (e.g. Vanham, 2016). Water has other uses related with regulation, functional, and cultural services, like navigation, recreation and environmental uses. The global fresh-water use by humans is currently estimated at $2600 \mathrm{~km}^{3}$ per year, much more than the pre-industrial estimated value of $415 \mathrm{~km}^{3}$ per year (Rockström et al., 2009c).

\subsubsection{Industrial minerals and rocks}

One of the most precise ways to establish the stages of human evolution is based on the complexity of modelling and use of rocks and minerals for various purposes such as defence, hunting and fishing, colorant extraction, ornaments, containers, shelters and buildings. The most primitive tools were rough stone and later polished and prepared stone tools.

Industrial minerals and rocks are inorganic substances of economic value other than metal ores, mineral fuels, and gemstones (Bates, 1975; Jeffrey, 2006). Actually, these minerals and rocks (e.g. clay, granite, limestone, sand, feldspar, quartz, gypsum, phosphates, fluorite, graphite, magnesite, sulphur, talc, salt) are an exceptionally diverse and vital group of raw materials used in the manufacture of many products - ceramics, plastics, refractories, paper, pharmaceuticals - which underpin almost all aspects of human activity, infrastructure, and standard of living (Evans, 1992; Jeffrey, 2006).

\subsubsection{Metallic minerals}

The Metal Age was defined by the ability to extract metals like copper and iron from minerals, and is remembered as one of the most important steps in human evolution towards our modern society. Nevertheless, industrial minerals and rocks did not lose their importance, even when the smelting of ores and the working of metals had been discovered (Kuzvart, 1984). The initial simple procedures evolved into more complex metallurgic techniques that provide a huge diversity of metals that are nowadays mostly used in the production of metal alloys. Metallic minerals are mined as metalliferous ore deposits when quality, proportion of extractable metal, and the price of the metal make this mining profitable. The modern world relies on energy and metals. Vehicles, wires, computers, smartphones, and all other appliances and machines are the most visible applications of metals. The following are especially relevant: iron and steel metals (manganese, chromium, nickel, cobalt, molybdenum, tungsten, vanadium), base metals (copper, lead, zinc, tin), precious metals (gold, silver, platinum and platinum group metals), light metals (aluminium, magnesium), minor and speciality metals (mercury, antimony, arsenic, by-product electronic metals like selenium, tellurium, gallium, germanium, indium, cadmium and silicon, bismuth, zirconium, hafnium, titanium, rare earth elements, niobium, tantalum, lithium, beryllium, uranium and thorium) (Pohl, 2011).

\subsubsection{Fuel}

Extractable fuels are mostly of non-renewable geological origin, commonly referred to as fossil fuels (crude oil, natural gas and coal) and uranium for the production of electricity in nuclear power-plants. The importance of energy in today's society is unquestionable so, as long as it is not possible to rely on alternative energy sources that meet global needs, the use of extractable geological fuels is inevitable. The main products of crude oil refining are fuel (gasoline, jet fuel, diesel), asphalt, heavy fuel oil, and lubricants. In addition to these, the various types of plastics are made from by-products of crude refining, as well as thousands of other products like fertilizer, linoleum, perfume, insecticide, soap, vitamin capsules, tyres.

\subsubsection{Provisioning services to ecosystems}

The food chain is usually organized according to the different organisms' complexity and their role in ecosystems as producers, consumers, and decomposers. However, the food chain also depends on the supply of inorganic nutrients given by soils, whose generation and maintenance is largely provided by rocks and geological processes. The availability of these chemical nutrients in soils results from the weathering and disintegration of underlying rocks, with the formation of new minerals and the release of ions that are incorporated in biochemical processes. This is a slow process involving complex mineralogical and geochemical processes, usually in the presence of water. The food chain is also supported by energy, mostly solar energy, but there are particular ecosystems that rely on the Earth's internal heat released in hydrothermal vents.

\subsection{Cultural services}

Geodiversity elements provide non-tangible benefits to society in a spiritual or cultural way, culture here being considered in a broad perspective. Gray $(2013,2018)$ describes several examples showing that these elements contribute to the prosperity of communities and individuals in different ways, namely science, arts, history, education, and leisure. Among the different non-tangible benefits, we underline the ones associated with environmental quality (e.g., local landscape character; therapeutic landscapes for health \& wellbeing; medical geology); geotourism and leisure (e.g., spectacular mountain views; rock climbing; fossil collecting); cultural, spiritual and historic meanings (e.g., folklore; sacred sites; sense of place); artistic inspiration (e.g., geology in sculpture, literature, music, poetry, painting); social development (e.g., local geological societies; field trips); Earth history and knowledge (e.g., evolution of life; extinction; origin of landforms; palaeoenvironments, baseline studies for climate and pollution research; ice cores; sea-level change); and geoforensics (potential to use the characteristics of geological elements, usually soils and sediments, to link suspects to crime scenes).

\section{The use of extractable and non-extractable natural resources}

The different benefits provided by geodiversity elements and processes to ecosystems and societies are assured by extractable and nonextractable natural resources that support different types of uses, for example the economic, the scientific, and the educational (Fig. 1 and Table 1).

\subsection{Economic use of extractable resources}

During the above explanation about the contribution of geodiversity to provisioning services, several examples were given related to the economic use of extractable resources. In fact, mining is one the main economic activities that largely support many nations worldwide. The world's population annually consumes about 32 billion tonnes of nonrenewable mineral resources, valued at about $\$ 1123$ billion (Wagner and Wellmer et al., 2011). Many other national and global estimates of the economic value of geological resources and also of ecosystems services, point out to values difficult to understand on the scale of trillions of US dollars per year (e.g. Wagner and Wellmer et al., 2011; Costanza et al., 2014; McMahon and Moreira, 2014; Gordon ö Barron, 2013). 


\subsection{Scientific, educational and economic uses of non-extractable resources}

The use of non-extractable geodiversity elements contrasts with the traditional perspective of geological resources, usually associated with mines, quarries and drillings where minerals and rocks are exploited to be later processed as raw materials. In fact, some geological resources may provide benefits to society without being removed from their original place of occurrence. This means an in situ utilisation of rocks, minerals, fossils, soils, and landforms for specific types of usages, such as science, education, and also as an economical resource (Brilha, 2016).

The in situ occurrence of geodiversity elements with suitable characteristics to be used as a scientific resource is known as a geosite. A scientific use of geodiversity elements allows geoscientists to make advances in knowledge about the Earth and its evolution through time. These studies can be made directly in the field (e.g. using geophysical equipment or high-precision LIDAR scanning) or on samples collected from the field and later studied in the laboratory to obtain analytical data.

Certain geodiversity elements have certain characteristics that justify its educational usage by school teachers on field classes that allow students to observe, describe and learn about geodiversity, which is an essential teaching strategy to guarantee an effective geoscience education (Orion, 1993; Orion and Hofstein, 1994; Vasconcelos, 2017).

The implementation of touristic activities based on visiting and interpretation of geodiversity elements - geotourism (Dowling, 2011; Hose et al., 2011) - is a way to obtain an economic revenue out of this natural resource, without the need to open quarries, mines or drillings. This is the case of Uluru in Central Australia or Iguaçu waterfalls in the Brazil/Argentina border where landforms with high aesthetic value justify the arrival of geotourists and consequently the development of an economic activity with strong local and national impacts. Geotourism is not a synonym of geological tourism, which means that geotourists are not only interested in geology. Geotourism is a sustainable niche tourism that uses the geodiversity of a region to promote an integrated environmental and cultural interpretation of the area, with benefits for local communities that justifies the link between geotourism and cultural services in Fig. 1.

The set of geological sites in a certain area that have special values to justify non-extractable usages is generally known as geological heritage, or geoheritage in short (Reynard and Brilha, 2018a,b). Geoheritage is that part of geodiversity that is assessed as worthy of geoconservation (Gray, 2018). Also considered as geoheritage are certain specimens, mainly fossils, minerals, rocks, or meteorites, once these samples are available to researchers in properly-managed scientific collections. Geoheritage, together with biodiversity, constitutes the natural heritage of our planet that is at risk due to anthropic and natural factors. This is why there is a need to implement legal and management measures - geoconservation - to protect geoheritage. Geoconservation consists on specific methods and actions to guarantee the inventory and assessment of geoheritage, its legal protection, conservation and management (Henriques et al., 2011; Prosser, 2013; Brilha et al., 2015).

Geoconservation aims to give geoheritage a proper conservation status, which is crucial for its international recognition. Since 1972, UNESCO recognizes geoheritage of outstanding universal value in the well-known World Heritage List. Today, there are 90 listed properties displaying top-class geoheritage (under criterion viii), which means $8 \%$ of the total properties in the list. Since 2015, UNESCO has a second mechanism to distinguish geological heritage: UNESCO Global Geoparks (Henriques and Brilha, 2017). Geoparks are territories with geoheritage of international importance where geotourism and educational strategies foster the sustainable development of local communities (McKeever and Zouros, 2005). There are today 140 UNESCO Global Geoparks in 38 countries around the globe but the tendency is to increase these in the coming years.

Geoconservation assures the maintenance of geoheritage and for this reason can be considered a way of sustainable management of nonextractable natural resources. Together with a correct management of extractable natural resources - geoplanning - governments can make a proper administration of all geodiversity and its georesources (Fig. 1), which is absolutely essential for our common future.

\section{Georesources and sustainability: the big picture}

As discuss above, geodiversity elements deliver their benefit either with or without the need to be extracted. As these services sustain society in so many different ways, geodiversity elements are considered natural resources whose proper management is essential for the achievement of global targets such as the UN Sustainable Development Goals - Agenda 2030 (Gill, 2017).

Sustainability is a concept closely linked with the management and conservation of resources for future generations, and so, renewable and non-renewable resources should be observed in different perspectives. Soils and water, as the foundation of life, should receive greater attention by society. In spite of soils being renewable resources from a geological perspective, their loss at today's rates cannot be compensated by new soil formation on a human time scale. A sustainable use of fresh water is only possible if reservoirs and aquifers are properly managed taking into account the natural balance of a healthy water cycle. The heavy contamination of the Earth's surface with pollutants compromises the capacity of rocks to regenerate the quality of fresh water, one of the essential regulating services delivered by these geodiversity elements.

Regarding mineral and fossil energy resources it is inappropriate to speak about their sustainability in the same way as biological resources (Shields et al., 2006). Antimony, molybdenum and zinc are examples of the scarcest mineral resources that may be exhausted within several decades to a century, if their extraction continues to increase (Henckens et al., 2016). We need these raw materials just as we need petroleum products. The exploitation and use of these resources have an inevitable impact on the environment that needs to be minimized in the same way as the effects of deforestation and intensive use of soil.

Despite our dependence of non-renewable resources, their exploitation and use has serious environmental impacts. Reinforcement of the 3Rs policies (reduce, reuse, recycle) and other solutions for the partial replacement of several raw materials are needed. Nevertheless, looking for instance at the so-called alternative energies, it should be noted that the production of these energies need of a huge amount of raw materials, including fuel, and rare earth metals, for the manufacture of products such as windmills, solar panels or batteries, with a considerable environmental impact.

\section{Concluding remarks}

The diversity of nature, which includes biotic and abiotic elements, is the key for the sustainability of human society. However, all international and most national agreements and policies, including the Rio Earth Summit and UN Sustainable Development Goals, are heavily weighted to biotic nature and barely include any abiotic elements. Furthermore, in Europe the EU nature conservation policy is entirely based on the Birds and Habitats Directives and so excludes geodiversity from any effective conservation action. All this is very detrimental to an integrated and sustainable approach to managing the Earth's surface and its environmental resources. Among the $17 \mathrm{UN}$ Sustainable Development Goals, geological materials/processes and their management are relevant to the implementation of targets included in 12 of these goals (Gill, 2017) yet they receive little recognition in the documentation. In fact, our modern human society benefits greatly from living on a geodiverse planet but this reliance is not reflected in public understanding or public policy. For example, without geodiversity there would be very little biodiversity. And as an example of the public's reliance on geodiversity, we can mention that the ubiquitous 
smartphone contains over half the non-radioactive elements in the periodic table (Rohrig, 2015; Miodownik, 2016) all of which are extracted from the lithosphere, yet the public is barely aware of this fact.

There is a particular contradiction in that the natural capital approach usually includes geology whereas the ecosystem services concept does not. This fact compromises the achievement of effective results and ignores the scientific knowledge that demonstrates the close interrelation between natural biotic and abiotic processes. Any disturbance in one of these processes may cause effects in others, independently of their biotic or abiotic nature.

This paper is intended to demonstrate to a variety of scientific communities (geoscientists, biologists, ecologists), in a clear way, how geodiversity interlinks with other natural systems and, in particular, how it is a determinant to guarantee human sustainability based on the use of extractable and non-extractable physical resources.

\section{Acknowledgements}

This work is co-funded by the European Union through the European Regional Development Fund, based on COMPETE 2020 (Programa Operacional da Competitividade e Internacionalização), project ICT (UID/GEO/04683/2013) with reference POCI-01-0145FEDER-007690 and Portuguese national funds provided by Fundação para a Ciência e Tecnologia.

\section{References}

Araujo, A., Pereira, D.I., 2017. A new methodological contribution for the geodiversity assessment: applicability to Ceará State (Brazil). Geoheritage. http://dx.doi.org/10 1007/s12371-017-0250-3.

Argyriou, A.V., Sarris, A., Teeuw, R.M., 2016. Using geoinformatics and geomorphometrics to quantify the geodiversity of Crete, Greece. Int. J. Appl. Earth Obs. Geoinf. $51,47-59$.

Australian Heritage Commission, 1996. Australian Natural Heritage Charter, 1st edn. Australian Heritage Commission, Canberra.

Australian Heritage Commission, 2002. Australian Natural Heritage Charter, 2nd edn. Australian Heritage Commission, Canberra.

Barbier, E.B., 2011. Capitalizing on Nature: Ecosystems as Natural Assets. Cambridge University Press, Cambridge.

Barbier, E.B., Heal, G.M., 2006. Valuing ecosystem services. Economists' Voice 3 (3), 1-6.

Bates, R.L., 1975. Introduction. In: Lefond, S.J. (Ed.), Industrial Minerals and Rocks, 4th edition. AIME, New York.

Benito-Calvo, A., Pérez-González, A., Magri, O., Meza, P., 2009. Assessing regional geodiversity: the Iberian Peninsula. Earth Surf. Process Landforms 34 (10), 1433-1445. http://dx.doi.org/10.1002/esp.1840.

Bradbury, J., 2014. A keyed classification of natural geodiversity for land management and nature conservation purposes. Proceedings of the Geologists' Association 125, 329-349.

Brilha, J., 2015. Concept of geoconservation. In: Tiess, G., Majumder, T., Cameron, P. (Eds.), Encyclopedia of Mineral and Energy Policy. Springer-Verlag, Berlin, Heidelberg. http://dx.doi.org/10.1007/978-3-642-40871-7_2-1. 2p.

Brilha, J., 2016. Inventory and quantitative assessment of geosites and geodiversity sites: a review. Geoheritage 8 (2), 119-134.

Brouwer, R., Brander, L., Kuik, O., Papyrakis, E., Bateman, I., 2013. A Synthesis of Approaches to Assess and Value Ecosystem Services in the EU in the Context of TEEB, Final Report. Free University, Amsterdam.

Brown, C., Walpole, M., Simpson, L., Tierney, M., 2011. Chapter 1: Introduction to the UK National Ecosystem Assessment Technical Report. UNEP-WCMC, Cambridge, pp. $1-10$.

Carcavilla, L., López-Martínez, J., Durán, J.J., 2007. Patrimonio geológico y geodiversidad: investigación, conservación, gestión y relación con los espacios naturales protegidos. Instituto Geológico y Minero de España, Serie Cuadernos del Museo Geominero, $\mathrm{n}^{\circ}$ 7, Madrid $360 \mathrm{p}$.

Costanza, R., de Groot, R., Sutton, P., van der Ploeg, S., Anderson, J., Kubiszewsy, I., Farber, S., Turner, R.K., 2014. Changes in the global value of ecosystem services. Global Environ. Change 26, 152-158.

Costanza, R., de Groot, R., Braat, L., Kubiszewski, I., Fioramonti, L., Sutton, P., Farber, S., Grasso, M., 2017. Twenty years of ecosystem services: how far have we come and how far do we still need to go? Ecosyst. Services 28, 1-16.

Daily, G.C. (Ed.), 1993. Nature's Services: Societal Dependence on Natural Ecosystems. Island Press, Washington DC.

Diaz, S., et al., 2015. The IPBES conceptual framework - connecting nature and people (83 co-authors). Curr. Opin. Environ. Sustain. 14, 1-16.

Dowling, R.K., 2011. Geotourism's global growth. Geoheritage 3 (1), 1-13.

Dunlop, L., Larwood, J.G., Burek, C., 2018. Geodiversity action plans - a method to facilitate, structure, inform and record action for geodiversity. In: Reynard, E., Brilha, J. (Eds.), Geoheritage: Assessment, Protection and Management. Elsevier, pp. 53-65.
Evans, A., 1992. Ore Geology and Industrial Minerals: An Introduction, third edition. Wiley Publishing.

Ferrero, E., Giardino, M., Lozar, F., Giordano, E., Belluso, E., Perotti, L., 2012. Geodiversity action plans for the enhancement of geoheritage in the Piemonte region (North-Western Italy). Annals Geophys. 55 (3), 487-495.

Forte, J., Brilha, J., Pereira, D.I., Nolasco, M., 2018. Kernel density applied to the quantitative assessment of geodiversity. Geoheritage. http://dx.doi.org/10.1007/ s12371-018-0282-3.

Gill, J.C., 2017. Geology and the sustainable development goals. Episodes 40 (1), 70-76.

Gordon, J.E., 2012. Engaging with geodiversity: 'Stone Voices', creativity and ecosystem cultural services in Scotland. Scott. Geographical J. 128 (3-4), 240-265.

Gordon, J.E., Barron, H.F., 2011. Scotland's Geodiversity: Development of the Basis for a National Framework. Scottish Natural Heritage Commissioned Report, pp. 417.

Gordon, J.E., Barron, H.F., 2012. Valuing geodiversity and geoconservation: developing a more strategic ecosystem approach. Scott. Geographical J. 128, 278-297.

Gordon, J.E., Barron, H.F., 2013. The role of geodiversity in delivering ecosystem services and benefits in Scotland. Scott. J. Geol. 49 (1), 41-58.

Gordon, J.E., Barron, H.F., Hansom, J.D., Thomas, M.F., 2012. Engaging with geodiversity - why it matters. Proceedings of the Geologists' Association 123 (1), 1-6.

Gray, M., 2008. Geodiversity: the origin and evolution of a paradigm. In: In: Burek, C.D., Prosser, C.D. (Eds.), The History of Geoconservation 300. Geological Society of London, pp. 31-36 Special Publication.

Gray, M., 2011. Other nature: geodiversity and geosystem services. Environ. Conserv. 38, 271-274.

Gray, M., 2012. Valuing geodiversity in an "ecosystem services" context. Scott. Geog. J. $128,177-194$.

Gray, M., 2013. Geodiversity: Valuing and Conserving Abiotic Nature, 2nd ed. Wiley Blackwell, Chichester, UK.

Gray, M., 2018. Geodiversity: the backbone of geoheritage and geoconservation. In: Reynard, E., Brilha, J. (Eds.), Geoheritage: Assessment, Protection and Management. Elsevier, pp. 13-25.

Gray, M., Gordon, J.E., Brown, E.J., 2013. Geodiversity and the ecosystem approach: the contribution of geoscience in delivering integrated environmental management. Proc. Geol. Assoc. 124 (4), 659-673.

Haines-Young, R., 2016. Report of Results of a Survey to Assess the Use of CICES, 2016. Support to EEA Tasks Under the EU MAES Process. Negotiated Procedure No. EEA/ NSS $/ 16 / 002$.

Haines-Young, R., Potschin, M., 2013. Common International Classification of Ecosystem Services (CICES): Consultation on Version 4, August-December 2012, EEA Framework Contract No. EEA/IEA/09/003.

Haines-Young, R., Potschin, M., 2018. Common International Classification of Ecosystem Services (CICES) V5.1: Guidance on the Application of the Revised Structure. www. cices.eu.

Helm, D., 2015. Natural Capital: Valuing the Planet. Yale University Press, New Haven and London.

Henckens, M.L.C.M., Driessen, P.P.J., Ryngaert, C., Worrell, E., 2016. The set-up of an international agreement on the conservation and sustainable use of geologically scarce mineral resources. Resour. Policy 49, 92-101.

Henriques, M.H., Pena dos Reis, R., Brilha, J., Mota, T., 2011. Geoconservation as an emerging geoscience. Geoheritage 3 (2), 117-128.

Henriques, M.H., Brilha, J., 2017. UNESCO Global Geoparks: a strategy towards global understanding and sustainability. Episodes 40 (4), 349-355.

Hjort, J., Luoto, M., 2010. Geodiversity of high-latitude landscapes in northern Finland. Geomorphology 115 (1-2), 109-116.

Hjort, J., Heikkinen, K., Luoto, M., 2012. Inclusion of explicit measures of geodiversity improve biodiversity models in a boreal landscape. Biodivers. Conserv. 21, 3487-3506.

Hjort, J., Gordon, J.E., Gray, M., Malcolm, L., Hunter, Jr., 2015. Why geodiversity matters in valuing nature's stage. Conserv. Biol. 29 (3), 630-639.

Hjort, J., Luoto, M., 2012. Can geodiversity be predicted from space? Geomorphology 153-154, 74-80.

Hose, T.A., Markovic, S.B., Komac, B., Zorn, M., 2011. Geotourism - a short introduction. Acta Geog. Slovenica 51 (2), 339-342.

Jačková, K., Romportl, D., 2008. The relationship between geodiversity and habitat richness in Sumava. National Park and Křivoklátsko Pla (Czech Republic): a quantitative analysis approach. J. Landsc. Ecol. 1, 23-38.

Jaramillo, F., Destouni, G., 2015. Comment on "Planetary boundaries: guiding human development on a changing planet". Science 348 (6240) 1217-c.

Jeffrey, K., 2006. Characteristics of the industrial minerals Sector. In: Kogel, Trivedi, Barker, Krukowski (Eds.), Industrial Minerals and Rocks - Commodities, Markets and Uses. Society for Mining, Metallurgy, and Exploration.

Johansson, C.E. (Ed.), 2000. Geodiversitet i Nordisk Naturvård. Nordisk Ministerråad, Copenhagen.

Karabulut, A., Egoh, B., Lanzanova, D., Grizzetti, B., Bidoglio, G., Pagliero, L., Bouraoui, F., Aloe, A., Reynaud, A., Maes, J., Vandecasteele, I., Mubareka, S., 2016. Mapping water provisioning services to supportthe ecosystem-water-food-energy nexus in the Danube river basin. Ecosyst. Serv. 17, 278-292.

Kiernan, K., 1996. The Conservation of Glacial Landforms. Forest Practices Unit, Hobart.

Kiernan, K., 1997. The Conservation of Landforms of Coastal Origin. Forest Practices Board, Hobart.

Kot, R., 2015. The point bonitation method for evaluating geodiversity: a guide with examples (Polish Lowland). Geografiska Annaler: Ser. A, Phys. Geogr. 97 (2), 375-393.

Kozłowski, S., 2004. Geodiversity. The concept and scope of geodiversity. Przegląd Geologiczny 52 (8/2), 833-837.

Kuzvart, M., 1984. Industrial Minerals and Rocks. Elsevier, Amsterdam. 
Malinowska, E., Szumacher, I., 2013. Aplication of landscape metrics in the evaluation of geodiversity. Miscellanea Geog. Reg. Stud. Dev. 17 (4), 28-33.

Manosso, F.C., Nóbrega, M.T., 2016. Calculation of geodiversity from landscape units of the Cadeado range region in Paraná, Brazil. Geoheritage 8 (3), 189-199.

Marshak, S., 2012. Earth: Portrait of a Planet. W.W. Norton and Co., New York.

Martinez-Grana, A.M., Goy, J.L., Cimarra, C., 2015. 2D to 3D geologic mapping transformation using virtual globes and flight simulators and their applications in the analysis of geodiversity in natural areas. Environ. Earth Sci. 73 (12), 8023-8034.

Mata-Perelló, J.M., Mata-Lleonart, R., Vintró-Sánchez, C., 2011. A new classification of geological resources. Dyna 78 (170), 243-249.

McKeever, P., Zouros, N., 2005. Geoparks: celebrating earth heritage, sustaining local communities. Episodes 28 (4), 274-278.

McMahon, G., Moreira, S., 2014. The Contribution of the Mining Sector to Socioeconomic and Human Development. Extractive Industries for Development Series \#30. World Bank, Oil, Gas, and Mining Unit Working Paper. .

Melelli, L., 2014. Geodiversity: a new quantitative index for natural protected areas enhancement. GeoJournal Tourism Geosites 1 (13), 27-37.

Millennium Ecosystem Assessment, 2005. Ecosystems and Human Well-Being: a Framework for Assessment. Island Press, Washington DC.

Milton, K., 2002. Loving Nature: Towards an Ecology of Emotion. Routledge London.

Miodownik, M., 2016. Materials for the 21st century: what will we dream up next? MRS Bull. 40, 1188-1196.

Najwer, A., Borysiak, J., Gudowicz, J., Mazurek, M., Zwoliński, Z., 2016. Geodiversity and biodiversity of the postglacial landscape (Dębnica river catchment, Poland). Quaestiones Geog. 35 (1), 5-28.

Nordic Council of Ministers, 2003. Diversity in Nature. Nordic Council of Ministers, Copenhagen.

Orion, N., 1993. Model for the development and implementation of field trip as an integral part of the science curriculum. Sch. Sci. Math. 93 (6), 325-331.

Orion, N., Hofstein, A., 1994. Factors that influence learning during a scientific field trip in a natural environment. J. Res. Sci. Teach. 31 (10), 1097-1119.

Panizza, M., 2009. The geomorphodiversity of the Dolomites (Italy): a key of geoheritage assessment. Geoheritage 1, 33-42.

Pellitero, R., Manosso, F.C., Serrano, E., 2014. Mid- and large-scale geodiversity calculation in Fuentes Carrionas (NW Spain) and Serra do Cadeado (Paraná, Brazil): methodology and application for land management. Geogr. Annaler Ser. A, Phys. Geogr. 97, 219-235.

Pereira, D.I., Pereira, P., Brilha, J., Santos, L., 2013. Geodiversity assessment of Paraná State (Brazil): an innovative approach. Environ. Manage. 52, 541-552.

Pohl, W., 2011. Economic Geology: Principles and Practice: Metals, Minerals, Coal and Hydrocarbons Introduction to Formation and Sustainable Exploitation of Mineral Deposits. John Wiley \& Sons.

Prosser, C.D., 2013. Our rich and varied geoconservation portfolio: the foundation for the future. Proc. Geol Assoc. 124, 568-580.

Räsänen, A., Kuitunen, M., Hjort, J., Vaso, A., Kuitunen, T., Lensu, A., 2016. The role of landscape, topography, and geodiversity in explaining vascular plant species richness in a fragmented landscape. Boreal Environ. Res. 21, 53-70.

Reynard, E., Brilha, J. (Eds.), 2018. Geoheritage: Assessment, Protection, and Management. Elsevier, Amsterdam.

Reynard, E., Brilha, J., 2018b. Geoheritage: a multidisciplinary and applied research topic. In: Reynard, E., Brilha, J. (Eds.), Assessment, Protection, and Management. Elsevier, Amsterdam, pp. 3-9.

Rockström, J., Falkenmark, M., Karlberg, L., Hoff, H., Rost, S., Gerten, D., 2009a. Future water availability for global food production: the potential of green water for increasing resilience to global change. Water Res. Res. 45, W00A.

Rockström, J., Steffen, W., Noone, K., Persson, A., Chapin, F.S., Lambin, E.F., Lenton, T.M., Scheffer, M., Folke, C., Schellnhuber, H.J., Nykvist, B., de Wit, C.A., Hughes, T., van der Leeuw, S., Rodhe, H., Sorlin, S., Snyder, P.K., Costanza, R., Svedin, U., Falkenmark, M., Karlberg, L., Corell, R.W., Fabry, V.J., Hansen, J., Walker, B., Liverman, D., Richardson, K., Crutzen, P., Foley, J.A., 2009b. Planetary boundaries: exploring the safe operating space for humanity. Ecol. Soc. 14 (2) Art. 32. [online]
URL: http://www.ecologyandsociety.org/vol14/iss2/art32/.

Rockström, J., Steffen, W., Noone, K., Persson, A., Chapin, F.S., Lambin, E.F., Lenton, T.M., Scheffer, M., Folke, C., Schellnhuber, H.J., Nykvist, B., de Wit, C.A., Hughes, T., van der Leeuw, S., Rodhe, H., Sorlin, S., Snyder, P.K., Costanza, R., Svedin, U., Falkenmark, M., Karlberg, L., Corell, R.W., Fabry, V.J., Hansen, J., Walker, B., Liverman, D., Richardson, K., Crutzen, P., Foley, J.A., 2009c. A safe operating space for humanity. Nature 461, 472-475.

Rohrig, B., 2015. Smartphones: smart chemistry. Chem. Matters (April/May), 10-12.

Ruban, D.A., 2010. Quantification of geodiversity and its loss. Proc. the Geol. Assoc. 121, 326-333.

Santucci, V., 2005. Historical perspectives on biodiversity and geodiversity. Geodivers. Geoconserv. 22 (3), 29-34.

Serrano, E., Ruiz-Flaño, P., 2007. Geodiversity. A theoretical and applied concept. Geogr. Helvetica 62, 140-147.

Sharples, C., 1993. A Methodology for the Identification of Significant Landforms and Geological Sites for Geoconservation Purposes. Forestry Commission Tasmania.

Shields, D.J., Solar, S.V., Langer, W.H., 2006. Sustainable development and industrial minerals in industrial minerals \& rocks: commodities, markets, and uses. In: Kogel, J.E., Trivedi, N.C., Barker, J.M., Krukowski, S.T. (Eds.), Society for Mining, Metallurgy, and Exploration, pp. 1548 USA.

Silva (Coord.), C.R., 2008. Geodiversidade do Brasil: conhecer o passado para entender o presente e prever o futuro. CPRM - Serviço Geológico do Brasil, Rio de Janeiro 264 p.

Silva, J., Rodrigues, C., Pereira, D., 2015. Mapping and analysis of geodiversity indices in the Xingu River basin, Amazonia, Brazil. Geoheritage 7, 337-350.

Silva, J.P., Pereira, D.I., Aguiar, A.M., Rodrigues, C., 2013. Geodiversity assessment of the Xingu drainage basin. J. Maps 9 (2), 254-262.

Steffen, W., Richardson, K., Rockström, J., Cornell, S.E., Fetzer, I., Bennett, E.M., Biggs, R., Carpenter, S.R., De Vries, W., De Wit, C.A., Folke, C., Gerten, D., Heinke, J., Mace, G.M., Persson, L.M., Ramanathan, V., Reyers, B., Sörlin, S., 2015. Planetary boundaries: guiding human development on a changing planet. Science 347 (6223) 1259855-1-1259855-10.

Tansley, A.G., 1935. The use and abuse of vegetational terms and concepts. Ecology 16, 284-307.

TEEB, 2010. The Economics of Ecosystems and Biodiversity: Mainstreaming the Economics of Nature: a Synthesis of the Approach, Conclusions and Recommendations of TEEB.

Tukiainen, H., Bailey, J.J., Field, R., Kangas, K., Hjort, J., 2016. Combining geodiversity with climate and topography to account for threatened species richness. Conserv. Biol. 31 (2), 364-375.

UK National Ecosystem Assessment, 2011. National Ecosystem Assessment: Synthesis of Key Findings. Department of Environment Food and Rural Affairs, London.

Van der Meulen, E.S., Braat, L.C., Brils, J.M., 2016. Abiotic flows should be inherent par of ecosystem services. Ecosyst. Serv. 19, 1-5.

Van Ree, C.C.D.F., Beukering, P.J.H., 2016. Geosystem services: a concept in support of sustainable development of the subsurface. Ecosyst. Serv. 20, 30-36.

Vanham, D., 2016. Does the water footprint concept provide relevant information to address the water-food-energy-ecosystem nexus? Ecosyst. Serv. 17, 298-307.

Vasconcelos, C. (Ed.), 2017. Geoscience Education: Indoor and Outdoor. Springer.

Wagner, M., Wellmer, F.W., et al., 2011. Global mineral resources, occurrence and distribution. In: In: Hasan, Syed E. (Ed.), Environmental and Engineering Geology, volume III EOLSS Publications.

Wiedenbein, F.W., 1993. Ein Geotopschutzkonzept für Deutschland. In: Quasten, H. (Ed.), Geotopschutz, probleme der methodik und der praktischen umsetzung. 1 Jahrestagung der AG Geotopschutz, Otzenhausen/Saarland, 17. University de Saarlandes, Saarbrucken.

Zwoliński, Z., 2009. The routine of landform geodiversity map design for the Polish Carpathian Mts. Landf. Anal. 11, 79-87.

Zwoliński, Z., Najwer, A., Giradino, M., 2018. Methods for assessing geodiversity. In: Reynard, E., Brilha, J. (Eds.), Geoheritage: Assessment, Protection, and Management. Elsevier, pp. 27-52. 